Raeesa MOOLLA

Nico KOTZE

Liz BLOCK

\title{
Housing satisfaction and quality of life in RDP houses in Braamfischerville, Soweto: A South African case study
}

The African National Congress (ANC) government initiated the building of Reconstruction and Development Programme (RDP) housing units in order to provide housing to the previously disadvantaged and to address the severe housing backlog that has developed in South Africa in recent years. However, in spite of the good intentions, there has been profound criticism with regard to the inferior building standards and quality of these housing units, as well as the lack of services and amenities in these development projects. The research for this paper was conducted in 2008. The residents of the Braamfischerville area in Soweto were chosen as sample respondents. Aspects such as demographic data, monthly income and monthly expenses were ascertained for each household using a systematic questionnaire. The level of satisfaction with regard to specific housing attributes such as the house itself, windows, doors, the roof and so on was rated using a five-point Likert Scale and determined from interviews. It was also found that residents identified proximity to basic services and amenities as being equally important as the appearance of the property as a contributing factor leading to satisfaction. It therefore proved to be important to establish basic amenities near newly developed communities. The findings revealed that there were specific grievances concerning the quality of the housing units and access to basic services and amenities that reduced the level of satisfaction in terms of housing and that consequently had a negative impact on the quality of life of Braamfisherville residents.

Keywords: housing satisfaction, services, amenities, Soweto, South Africa 


\section{Introduction}

The history of South Africa in terms of its apartheid laws, which restricted movement and place of residence for the large majority of the country's inhabitants, continues to have repercussions on housing affordability, availability and accessibility, especially in the case of the poor. A serious lack of planning and development in the provision of low-cost homes for this sector of the community led the apartheid government to neglect the large population of black impoverished people to some extent (Sowman \& Urquhart, 1998). However, in the 1980s, when the influx-control laws that originally restricted the movement of black people were removed, the housing problem in the country was aggravated. For the first time, black people were allowed to move freely and reside where they preferred. This had its own set of consequences and resulted in rapid migration to urban areas, which resulted in the creation of slums and the development of informal settlements or squatter camps on the vacant land surrounding urban areas (Sowman \& Urquhart, 1998). Currently there is an extreme shortage of housing in South Africa. According to a report in April 2008, the housing backlog then stood at 2.3 million housing units (Bhengu, 2008).

In 1994 the first democratic African National Congress (ANC) government came to power in South Africa and it promised to increase the share of funding for the housing sector from just below $2 \%$ to $5 \%$ in the national budget in order to build one million housing units over the following five years. The vehicle used by the ANC-led government to rid the country of its apartheid legacy and to redress the inequalities in society that were proving to be detrimental to previously marginalised and disempowered groups was based on the government's primary policy document, the Reconstruction and Development Programme (RDP), which focuses on all facets of transformation (Fitchett, 2001; Donaldson \& Marais, 2002). This philosophy is based on six fundamental principles: first, it is an integrated and sustainable programme; second, it is a people-driven process; third, it strives to create peace and security for all; fourth, it attempts to eradicate a fragmented society separated into first-world and third-world components; fifth, it sets out to link reconstruction, development, growth and redistribution so that these processes do not contradict one another; and, finally, it embodies a democratisation process in which society (including members affected by past injustices) contributes to change (Donaldson \& Marais, 2002)

The official statistics on the number of housing units built during the first five years of the RDP Programme differ radically from those envisaged in the initially stipulated RDP objectives. "It seems that between 500,000 and 750,000 houses were constructed between 1994 and 1999" (Marais et al., 2002: 381). Nevertheless, homelessness is on the increase in South Africa, owing to rising levels of unemployment and a shortage of affordable housing (O'Leary, 2003). The housing backlog, together with the slow delivery of low-cost homes, has further widened the gap between homeowners and shack-dwellers. Aware of these deteriorating circumstances, in 2008 the South African government decided that it would set out to increase housing provision from 270,000 to 500,000 units every year until 2014, by which time it hopes to have been able to eradicate squatter camps and slum areas (Department of Housing, 2005, 2006; Bhengo, 2008).

The discussion on housing satisfaction and quality of life in the RDP housing development in Braamfischerville is divided into three sections with the following emphases: first, the quality of housing units and building standards; second, the availability of services and amenities; and, third, housing satisfaction and quality of life in the study area.

\section{Braamfischerville as a study area}

Braamfischerville is located in Soweto, south of Johannesburg. The RDP housing settlement here is on the border between Soweto and Roodepoort, but is part of Soweto. The development of the first of the four phases of RDP houses in Braamfischerville began in 1996. In 2002, two more phases were added, the housing units of which were of a similar structure to the two earlier phases. The houses in these developments are distinguished by their house numbers only; these follow a numerical order that is continuous through the four phases.

According to the government, these housing development projects will include the basic services (e.g., running water, sewerage and electricity) and amenities (e.g., schools and clinics) that are essential in any new community. However, according to a report in the newspaper Sowetan (Mohlala, 2002), six years into the development of this community many of the services were still absent. Furthermore, the infrastructure was also very limited. At that stage, for instance, there was only one temporary primary school with classrooms housed in shipping containers; a second primary school was built as part of Phase 3 and a high school was still under construction. In addition, there was no storm-water drainage system, nor were there any open spaces or parks for recreation in this neighbourhood (Mohlala, 2002). It was not until 2008 that the government started paving the main roads and beautifying the area by planting trees along the roads (Moolla, 2008).

In this case study, two hundred questionnaires were completed by households within the four phases of the RDP housing development of Braamfischerville. Fifty households in each 
of the four phases were randomly selected. The interviewees' household demographics and their housing satisfaction were measured using a five-point Likert scale.

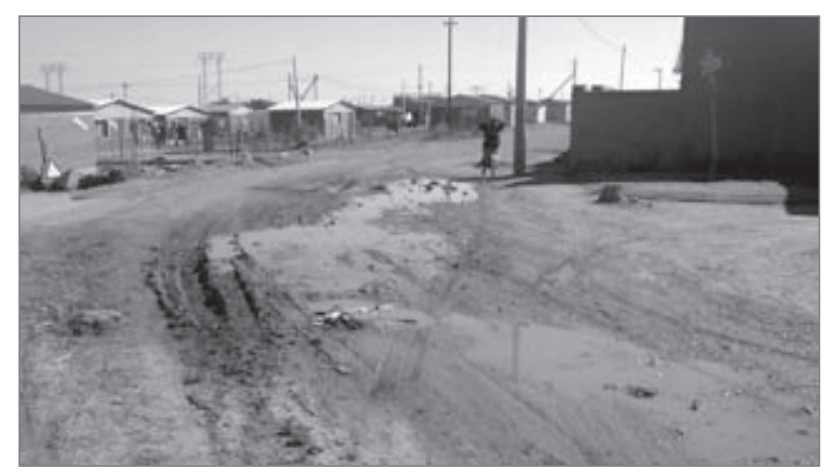

Figure 1: Houses and the depressing area in Braamfischerville (photo: Nico Kotze).

\section{Characteristics of housing units in Braamfischerville}

A typical house built in South Africa under the Reconstruction and Development Plan has an area of $36 \mathrm{~m}^{2}$ and is located on a $250 \mathrm{~m}^{2}$ lot (Thale, 2001; Cox, 2008). Each of the units consists of an open-plan bedroom, lounge and kitchen, with a separate lavatory. Generally, these homes are built with brick and mortar with galvanised iron roofs, metal doors and usually two or three small windows (Pollack, 2003; see Figure 2). Not all RDP homes are the same; some are bigger and can measure up to $45 \mathrm{~m}^{2}$. However, according to David Pottie (2003) only $30 \%$ of all houses built by the government were larger than $30 \mathrm{~m}^{2}$, and few of the houses constructed up to 1999 complied with the standard building regulations. On the other hand, local municipalities and provincial governments all have different specifications for RDP housing units, resulting in these discrepancies (Pottie, 2003). Nevertheless all of these houses have access to clean running water and are connected to a sewage system (Thale, 2001; Cox, 2008). The cost of a typical RDP home in 2006 was about ZAR 45,000 to 50,000 per unit (USD 1.00 = ZAR 7.25 at present; Cross et al., 2006). Nonetheless, due to inflation, these homes could cost much more two years down the line.

The building standards and quality of these housing units are at the forefront of the housing debate in South Africa because the government has yet to set a level of acceptable standards required for contractors and developers (Bond \& Khosa, 2002). Various communities have lodged numerous complaints levelled at the safety of the RDP homes. Questions have also recently been raised regarding the sustainability of these communities due to the lack of infrastructure in these newly developed areas (Rosenberger, 2003). According to some theorists, satisfaction levels among people living in poor communities

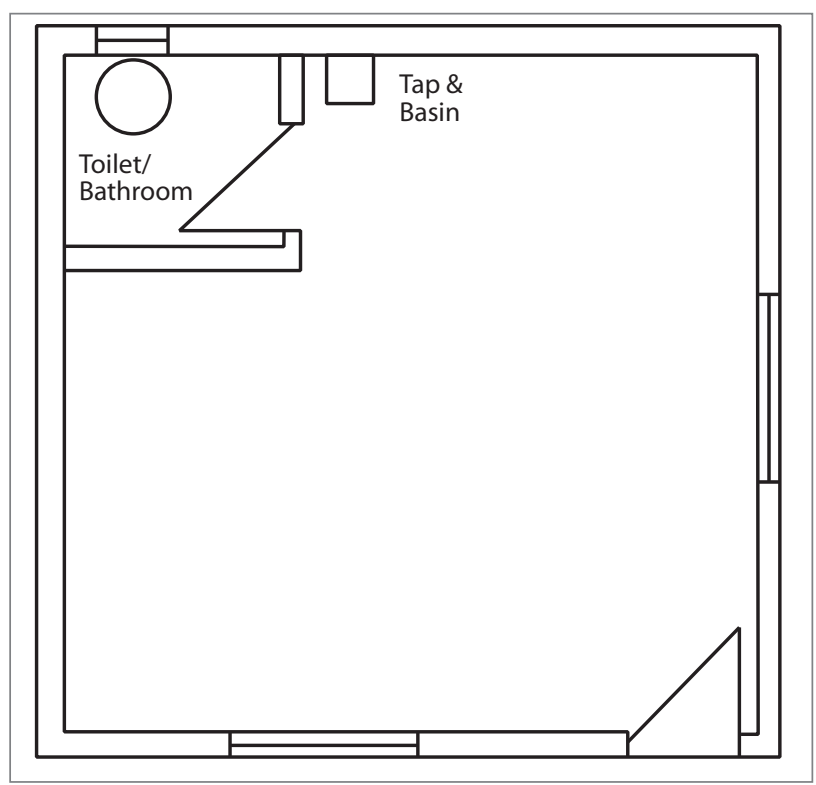

Figure 2: Floor plan of RDP housing unit in Braamfischerville (illustration: Nico Kotze).

are greater for those in self-built homes, such as shacks, than for those in government-built homes (Mehlomakulu \& Marais, 2000). This is not always true, however, because secure tenure, which is not always the case in self-built homes, could be a factor influencing housing satisfaction.

During the 2008 research in the Braamfischerville study area, it was found that the majority of the inhabitants of these RDP houses had issues with the quality of their housing units. Complaints from the occupants varied from roofs and walls that were improperly built due to poor craftsmanship to doors that did not open or close properly. The lack of air bricks in these housing units also led to high levels of dissatisfaction because windows have to be kept open for ventilation, resulting in dust entering the houses. Finally, the need for a proper kitchen and lavatory was also highlighted by the inhabitants of the study area, and $55 \%$ of the interviewees found the liveability of these houses extremely unsatisfactory. According to John Turner (1976), the value of a house is of greater importance to a person than the appearance of the housing unit. In addition, the structure of the house, even if the building material were of a lower standard, would not affect the person's perception if value could be attached to the unit. This is clearly evident from the results of this study; although the interviewees found individual aspects of the housing units problematic, the level of dissatisfaction with the total house was lower. Another significant factor was that, although more than $63.6 \%$ of the interviewees in the study area indicated that they were unemployed and $73 \%$ indicated that they had an income of less than ZAR 1,500 per month, almost $86 \%$ of the interviewees pointed out that they were the owners of the RDP houses, which represents secure tenure for the occupants. 


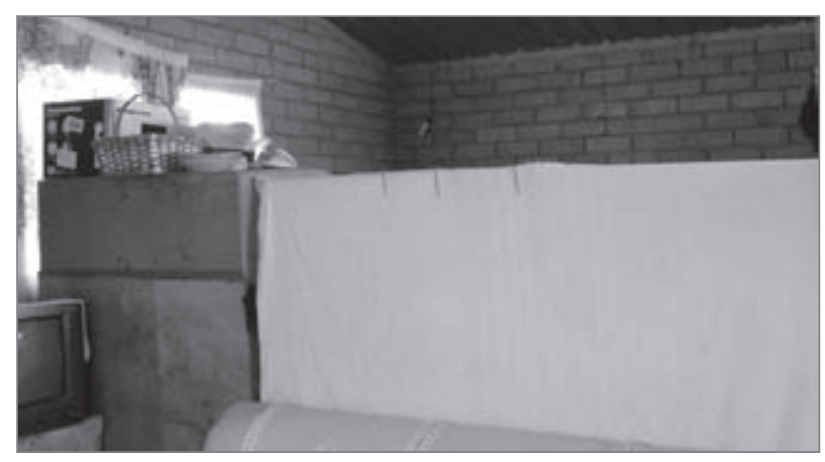

Figure 3: Inhabitants try to create privacy within the housing units (photo: Nico Kotze).

\section{Housing satisfaction in Braamfischerville}

The satisfaction levels concerning the RDP houses are examined in this section. According to Kobus Lazenby (1988: 55), "housing satisfaction can be defined as the level of satisfaction with a specific house within a chosen residential, physical and social environment, as well as its specific housing attributes." The first observation that must be made is that these inhabitants are first-time homeowners, most probably having lived in shacks or as backyard squatters in their previous accommodation. Nevertheless, from the averages in Table 1, it is clear that the majority of these people are dissatisfied to very dissatisfied with their RDP houses. In contrast, when the response to the total house is considered, more than $50 \%$ of the respondents stated that they are satisfied or very satisfied, but this must be viewed against the backdrop of the opening statement of this section.

The size of the houses was heavily criticised, with $66 \%$ of the respondents dissatisfied. Each of the RDP homes, on which this case study is based, has a floor area of $30 \mathrm{~m}^{2}$ and is built on a $250 \mathrm{~m}^{2}$ lot (Thale, 2001; Cox, 2008). This result is not an unusual phenomenon, however, because the size of these houses is perceived against the background of the size of most families and extended families that could be occupying them

Table 1: Satisfaction level with RDP homes in Braamfischerville (\%)

\begin{tabular}{llllll}
\hline Variables & $\begin{array}{l}\text { Very } \\
\text { dissatisfied }\end{array}$ & $\begin{array}{l}\text { Dissatis- } \\
\text { fied }\end{array}$ & Uncertain & Satisfied & $\begin{array}{l}\text { Very } \\
\text { satisfied }\end{array}$ \\
\hline Overall & 16.2 & 28.3 & 5.1 & 38.4 & 12.1 \\
\hline Size & 25.8 & 40.2 & 4.1 & 13.4 & 16.5 \\
\hline Roof & 14.4 & 46.4 & 0.0 & 33.0 & 6.2 \\
\hline Walls & 5.2 & 47.9 & 1.0 & 39.6 & 6.3 \\
\hline Doors & 13.4 & 50.5 & 2.1 & 32.0 & 2.1 \\
\hline Windows & 21.0 & 40.0 & 6.0 & 31.0 & 2.0 \\
\hline Lavatory & 9.0 & 49.0 & 2.0 & 36.0 & 4.0 \\
\hline Kitchen & 28.1 & 45.8 & 2.1 & 13.5 & 10.4 \\
\hline Average & 16.6 & 43.5 & 2.8 & 29.6 & 7.5 \\
\hline
\end{tabular}

( $42 \%$ of the interviewees indicated that between five and ten people were living in the housing unit allotted to them). All of the components of the house were also severely criticised. Roofs with no ceilings (60.8\%), windows that must be left open because of the lack of air bricks (61\%), doors that are difficult to open and close (63.9\%) and, to a lesser extent, the walls $(53.1 \%)$ met with a high level of dissatisfaction. All of these complaints could be related to poor craftsmanship.

The kitchen area, which consists of only a tap and sink set into one of the walls, and the lavatory, which has only a toilet separated from the rest of the house by walls, elicited dissatisfaction levels of just under 74\% and 58\% respectively. These low values can be attributed to poor design and attempts by the housing authorities to keep the cost of the RDP houses as low as possible.

\section{Availability of services and amenities in Braamfischerville}

Rapid urbanisation in South Africa has exceeded municipal investment in infrastructure and services, predominantly in areas with a large proportion of impoverished households. Complex problems in housing policy and management, income distribution, infrastructure and service provision have subsequently come to the fore (Westaway, 2006). According to Turner (1967), the respondents also considered closer proximity to basic services and amenities to be more important than the appearance of the housing units. Close proximity to amenities and the workplace is imperative for economic reasons (monetary savings) and satisfaction. Low-income families may find that many of the government-built homes are not ideally located, therefore making it necessary to spend a great deal of money on transport, which could in turn lead to increased poverty. Because of these factors, public housing areas in South Africa are criticised for their poor locations (Mehlomakulu \& Marais, 1999).

Examining interviewees' perceptions in Braamfischerville with regard to proximity to services and amenities, it is clear that the majority believe that Spaza shops (informal convenience stores; $86 \%)$, taxi ranks or pick-up points (80\%) and primary schools (78\%) are within easy walking distance of their homes (see Table 2). In contrast to taxi ranks, the interviewees perceive other modes of transport - for example, bus depots and bus stops $(63 \%)$ and train stations $(6 \%)$ - to be less accessible.

In 2002, the Moses Khotane Primary School was the only school in Braamfischerville. It is still housed in a temporary structure. Since then a new primary school has been built in the neighbourhood (Phase 3). Thirty-eight percent of the interviewees indicated that high schools are located close to their houses (since 2002, one high school has been built in 
Table 2: Inhabitants' perception of proximity of services and amenities in Braamfischerville (\%).

\begin{tabular}{ll}
\hline Variables & Within easy walking distance \\
\hline Spaza shops & 86 \\
\hline Taxi ranks or pick-up points & 80 \\
\hline Primary schools & 78 \\
\hline Bus depot or bus stop & 63 \\
\hline High school & 38 \\
\hline Formal grocery shop & 38 \\
\hline Clinic & 31 \\
\hline Preschool & 18 \\
\hline Pension payout point & 7 \\
\hline Train station & 6 \\
\hline
\end{tabular}

the area). Only $18 \%$ of the respondents perceived preschools to be within easy walking distance of their homes. The clinics that the majority of the inhabitants visit for medical treatment are also rated low in terms of accessibility. Only $7 \%$ of the interviewees felt that pension payout points were within easy walking distance of their homes, which is a great disadvantage to the elderly, who are usually less mobile (see Table 2).

\section{Quality of life in Braamfischerville}

Black townships and informal settlements represent degraded living environments with inadequate infrastructure and poor social and recreational facilities. Abject poverty is especially prevalent in squatter encampments (Westaway, 2006). Even as early as 1968, during the apartheid era in South Africa, the Ministry of Housing acknowledged that the surrounding landscape plays a very important role in the viability of any settlement, especially in the case of new developments. It also represents a new standard of living for the community, which can be daunting (Mohlala, 2002). In a customer satisfaction survey conducted in 2000 by the Johannesburg Metropolitan Council, the respondents indicated that they found the total lack of (or inadequate access to) services and facilities problematic, as well as the quality of service delivery (Westaway, 2006). In the case of Braamfischerville, most of the services and infrastructure are lacking or poorly developed. According to the inhabitants, the city council only started to pave the main roads and beautify the area by planting trees along the roads in 2008. With no parks for recreational purposes, this is a very bleak area to live in.

All four phases of the Braamfisherville RDP development were developed in close proximity to a mine dump. The first three phases were built $350 \mathrm{~m}$ from this health hazard, but the final phase was developed only $100 \mathrm{~m}$ from it, causing the houses to fall into the dust zone of the mine dump. A second factor that exacerbates this problem is that no air bricks are used in these houses, and so windows must be kept open to allow for

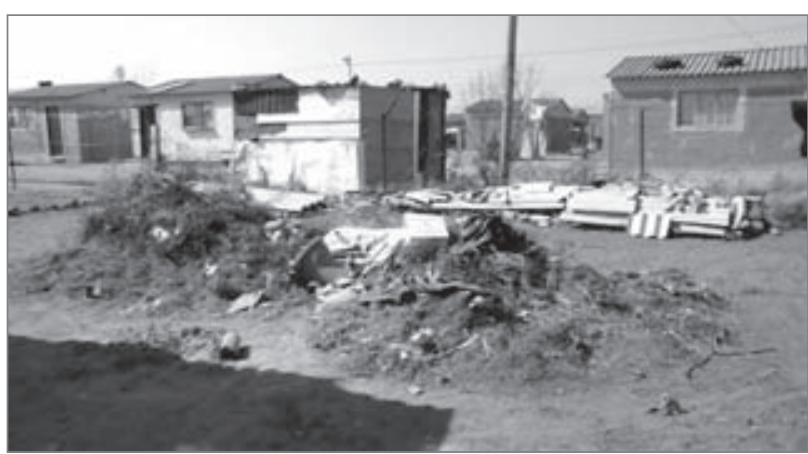

Figure 4: A home that burned down due to faulty wiring (photo: Raeesa Moolla).

air circulation. Consequently dust accumulates in these houses. These factors can adversely affect the health of the residents of the area. Another health risk to the inhabitants is that the houses in Phase 1 have asbestos roofs and no ceilings.

Quality of life in the study area is also under pressure because of the limited size of these housing units. The number of inhabitants per house is leading to serious overcrowding in the study area. Forty-two percent of the interviewees indicated that more than five and up to ten people occupy a $36 \mathrm{~m}^{2}$ housing unit, which consists of one open-space living area only. This results in a lack of privacy for the inhabitants that further reduces the quality of life.

\section{Conclusion}

Although RDP housing provides shelter for people that previously probably lived in shacks or as backyard squatters, the conditions within these developments are far from ideal. In this case study, interviewees strongly criticised the size of RDP houses as well as the kitchen and, to a lesser extent, the lavatory. This could be attributed to the poor design of these housing units and also to attempts by housing authorities to limit the cost of these houses as much as possible. Fault was also found with the roofs, windows and doors, but these three components could probably be associated with bad craftsmanship and cost-cutting practices by the developers.

With the high unemployment rate and a large proportion of the people in Braamfischerville earning a meagre monthly income of ZAR 1,500 (approximately USD 200) or even less, it is of utmost importance that all services and amenities be provided to reduce transport costs for the inhabitants. Unfortunately, this is not the case, the exception being taxi ranks or taxi pick-up points. Other modes of transport, such as bus depots, bus stops and train stations, were perceived by the inhabitants as more difficult to reach. Amenities that the government must provide (e.g., high schools, preschools, clinics and pension payout points) are lacking in the study area and the interviewees say that they are difficult to reach. 
The locations of these RDP developments in the Braamfisherville case study are also questionable because no proper amenities and services have been provided. The areas for all four phases of the Braamfisherville RDP housing development were located in close proximity to one another and thus within the dust zone of a mine dump, which could adversely affect the health of the residents. Quality of life in the study areas is also under pressure because of the limited size of these housing units. The number of inhabitants per house has led to serious overcrowding and a lack of privacy for the residents.

Although the RDP houses provide basic minimum accommodation for previously homeless people, they provide secure tenure to the majority of the residents. To improve the quality of life in these newly developed areas, the government will have to provide the necessary services and infrastructure to make the housing units liveable, and the communities occupying them viable. This would be preferable to simply providing a roof over the head of an impoverished person.

Raeesa Moolla

University of Johannesburg, Faculty of Science, Department of Geography, Environmental Management and Energy Studies,

Auckland Park, South Africa

E-mail: aeesamoolla@gmail.com

\section{Nico Kotze}

University of Johannesburg, Faculty of Science, Department of Geography, Environmental Management and Energy Studies, Auckland Park, South Africa

E-mail: nicok@uj.ac.za

\section{Liz Block}

University of Johannesburg, Faculty of Science, Department of Geography, Environmental Management and Energy Studies, Auckland Park, South Africa

E-mail: eblock@uj.ac.za

\section{References}

Bhengu, X. (2008) Housing delivery to receive a boost from new state agency. Sowetan News, 3 Apr. 2008, p. 16.

Bond, P. \& Khosa, M. (eds.) (2002) An RDP policy audit. Pretoria, Human Sciences Research Council.

Cox, A. (2008) Innovative ways sought to house Alex residents. The Star Newspaper, 28 Apr. 2008, p. 6

Cross, C., Kok, P., Wentzel, M. \& O'Donovan, M. (2005) Population and households in Johannesburg: Report to Johannesburg City Strategies. Pretoria, Human Sciences Research Council.

Department of Housing (2005) Pocket guide to South Africa 2005/2006: Housing. Pretoria.

Department of Housing (2006) Annual report: Breaking new ground in housing development. Pretoria.

Donaldson, R. \& Marais, L. (2002) Urban policy for urban change during transition: An introduction. In: Donaldson, R. \& Marais, L. (eds.) Transforming rural and urban spaces in South Africa during the 1990s: Reform, restitution, restructuring, pp. 179-202. Pretoria, Africa Institute of South Africa.

Fitchett, A. (2001) Contractor development through the provision of low-cost mass housing. Urban Forum, 12(3-4), pp. 352-364. DOI: 10.1007/s12132-001-0011-9

Lazenby, K. (1988) Bewoningsbevrediging in die blanke woonhuissektor binne die munisipaliteit van Bloemfontein: ' $n$ Studie van proses, patrone en strategie. Doctoral thesis. Bloemfontein, University of the Orange Free State.

Marais, L., Barnes, L. \& Schoeman, J. (2002) A provincial comparison of post-apartheid housing policy and delivery: The Free State and Northern Cape as case study. In: Donaldson, R. \& Marais, L. (eds.) Transforming rural and urban spaces in South Africa during the 1990s: Reform, restitution, restructuring, pp. 381-405. Pretoria, Africa Institute of South Africa.

Mehlomakulu, T. \& Marais, L. (2000) Dweller perceptions of public and self-built homes: Some evidence from Mangaung (Bloemfontein). Journal of Family Ecology and Consumer Sciences, 27(2), pp. 92-102.

Mohlala, T. (2002) A choice to move. Mail and Guardian Online Newspaper, 28 Sep. 2002.

Moolla, H. (2008) Board member of City Parks (interview, 28 Jun. 2008).

O'Leary, B. (2003) Changes in quality of life of Durban's residents between 1998 and 2002. Urban Health and Development Bulletin, 6(1-2), pp. 35-39.

Pollack, M. (2003) SA's "greenest" RDP houses are being built in Atlantis. Available at: http://www.capetown.gov.za/en/Pages/ RDPhousesarebuiltAtlantis.aspx (accessed 14 Sep. 2008).

Pottie, D. (2003) Housing the nation: The politics of low-cost housing policy in South Africa since 1994. Politeia, 22(1), pp. 119-143.

Rosenberger, I. K. (2003) Sustainable low-cost housing: A review of three low-cost housing developments in Gauteng Province. Master's dissertation. Johannesburg, Rand Afrikaans University.

Sowman, M. \& Urquhart, P. (1998) A place called home: Environmental issues and low-cost housing. Cape Town, University of Cape Town Press.

Thale, T. (2001) New plan for better housing. City of Johannesburg, 16 Nov. 2001. Available at: http://www.joburgnews.co.za/ november/housing.stm (accessed 10 Aug. 2008).

Turner, J. F. C. (1967) Barriers and channels for housing development in modernizing countries. Journal of American Institutional Planning, 23, pp. 67-181.

Turner, J. F. C. (1976) Housing by people: Towards autonomy in building environments. London, Marion Byers.

Westaway, M. S. (2006) A longitudinal investigation of satisfaction with personal and environmental quality of life in an informal South African housing settlement, Doornkop, Soweto. Habitat International, 30, pp. 175-189. DOI: 10.1016/j.habitatint.2004.09.003. 